University of Nebraska - Lincoln

DigitalCommons@University of Nebraska - Lincoln

\title{
Hypoxia affects performance traits and body composition of juvenile hybrid striped bass (Morone chrysops $x$ M. saxatilis)
}

\author{
Bartholomew W. Green \\ bart.green@usda.gov \\ Steven D. Rawles \\ USDA, Agricultural Research Service \\ Sidney A. Fuller \\ USDA, Agricultural Research Service \\ Benjamin H. Beck \\ USDA, Agricultural Research Service \\ Matthew E. McEntire \\ USDA, Agricultural Research Service
}

Follow this and additional works at: https://digitalcommons.unl.edu/usdaarsfacpub

Part of the Agriculture Commons, and the Aquaculture and Fisheries Commons

Green, Bartholomew W.; Rawles, Steven D.; Fuller, Sidney A.; Beck, Benjamin H.; and McEntire, Matthew E., "Hypoxia affects performance traits and body composition of juvenile hybrid striped bass (Morone chrysops x M. saxatilis)" (2016). Publications from USDA-ARS / UNL Faculty. 2423.

https://digitalcommons.unl.edu/usdaarsfacpub/2423

This Article is brought to you for free and open access by the U.S. Department of Agriculture: Agricultural Research Service, Lincoln, Nebraska at DigitalCommons@University of Nebraska - Lincoln. It has been accepted for inclusion in Publications from USDA-ARS / UNL Faculty by an authorized administrator of DigitalCommons@University of Nebraska - Lincoln. 


\title{
Hypoxia affects performance traits and body composition of juvenile hybrid striped bass (Morone chrysops $\times$ M. saxatilis)
}

\author{
Bartholomew W Green, Steven D Rawles, Sidney A Fuller, Benjamin H Beck \& \\ Matthew E McEntire \\ United States Department of Agriculture, Agriculture Research Service, Harry K. Dupree Stuttgart National Aquaculture \\ Research Center, Stuttgart, Arkansas, USA
}

Correspondence: B W Green, USDA-ARS, Harry K. Dupree Stuttgart National Aquaculture Research Center, P.O. Box 1050, 2955 Highway 130 East, Stuttgart, AR 72160, USA. E-mail: bart.green@ars.usda.gov

\begin{abstract}
Performance traits and body composition of juvenile hybrid striped bass (Morone chrysops $\times$ M. saxatilis) in response to hypoxia were evaluated in replicate tanks maintained at constant dissolved oxygen concentrations that averaged $23.0 \pm 2.3 \%, \quad 39.7 \pm 3.0 \%$ and $105.5 \pm$ $9.5 \%$ dissolved oxygen saturation. Fish were fed a commercially formulated feed daily to apparent satiation. Total feed intake and fish growth and yield increased linearly in response to increased dissolved oxygen concentration. Nutrient utilization was reduced significantly only at the greatest level of hypoxia. With the exception of whole body protein content, whole body compositional indices and nutrient retention efficiencies were linearly related to dissolved oxygen concentration. Results demonstrate that as hypoxia becomes more severe, juvenile hybrid striped bass feed intake is reduced, which affects growth and nutrient retention.
\end{abstract}

Keywords: dissolved oxygen, hybrid striped bass, hypoxia, Morone, nutrient retention, nutrient utilization

\section{Introduction}

Feeding fish to apparent satiation during the growing season in warm water aquaculture ponds ensures rapid fish growth. However, fish convert only about $20-30 \%$ of feed nitrogen to biomass and excrete the remainder as the metabolic by-product, ammonia (Boyd 1985; Porter, Krom,
Robbins, Brickell \& Davidson 1987; Krom \& Neori 1989; Siddiqui \& Al-Harbi 1999). Dense phytoplankton blooms typically develop in response to the high nutrient inputs from high feeding rates. Phytoplankton biomass is the main producer and consumer of dissolved oxygen in aquaculture ponds, and fish and benthic respiration combined can account for up to $40 \%$ of the oxygen budget (Boyd 1985). Photosynthetic oxygen production often exceeds total pond respiration in intensively managed ponds and dissolved oxygen (DO) concentration becomes super-saturated (Boyd 1990; Boyd, Watten, Goubier \& Wu 1994; Green, Rawles \& Beck 2012). However, after sunset, total pond respiration can decrease DO concentrations to levels that affect fish growth negatively or in extreme cases even threaten their survival (Boyd, Davis \& Johnston 1978; Boyd 1990; Green et al. 2012). Mechanical aerators operate nightly in intensively managed production ponds to supply additional DO to meet pond respiratory demands and maintain a minimum DO concentration (Boyd \& Tucker 1979; Green et al. 2012).

Hybrid striped bass (HSB, Sunshine bass, Morone chrysops Rafinesque $\times$ M. saxatilis Walbaum) reared in intensively managed fingerling or food fish production ponds will experience varying degrees of hypoxia nightly during summer months. The intensity of hypoxia depends on a variety of factors including fish biomass, feeding rate, phytoplankton bloom condition and installed aeration capacity. Fish actively avoid hypoxic waters where possible (Whitmore, Warren \& Doudoroff 1960; Spoor 1990; Pihl, Baden \& Diaz 
1991; Claireaux, Webber, Kerr \& Boutilier 1995; Wannamaker \& Rice 2000). For example, the European seabass (Dicentrarchus labrax Linneaus) will modify its daily vertical migration to remain in waters with $40 \%$ and greater DO saturation (Schurmann, Claireaux \& Chartois 1998). However, fish in aquaculture ponds have few options to avoid severe hypoxic conditions, with the main response being behavioral - fish will move to the pond surface to pass oxygen-saturated surface layer water over their gills (Burggren 1982) and/ or congregate around the discharge of the aerator.

Effects of hypoxia on fish growth are reported in numerous studies conducted in tanks and aquaria. Under conditions of severe hypoxia (20-25\% DO saturation), growth of juvenile channel catfish (Ictalurus punctatus Rafinesque; Carlson, Blocher \& Herman 1980; Buentello, Gatlin \& Neill 2000), juvenile yellow perch (Perca flavescens Mitchill; Carlson et al. 1980) and largemouth bass (Micropterus salmoides Lacepede; Stewart, Shumway \& Doudoroff 1967) in tanks or aquaria was $45 \%$, $70 \%$ and $28 \%$, respectively, of that for fish maintained at normoxia (90-100\% DO saturation). Growth of European sea bass in tanks at moderate hypoxia (40-63\% DO saturation) was significantly lower compared to fish held at normoxia (86-103\% DO saturation; Thetmeyer, Waller, Black, Inselmann \& Rosenthal 1999; Pichavant, Person-Le-Ruyet, Le Bayon, Severe, Le Roux \& Boeuf 2001). No reports of the hypoxia tolerance of HSB were found in the literature.

Slower growth observed for fish exposed to hypoxic conditions is linked to reduced feed intake. Compared to fish in normoxic waters, feed intake by fish in moderately hypoxic waters was $25-54 \%$ lower and in severely hypoxic waters it was up to 75\% lower (Glencross 2009; Burt, Hamoutene, Perez-Casanova, Gamperl \& Volkoff 2014; TranDuy, van Dam \& Schrama 2012). Feed conversion ratio or feed conversion efficiency under moderate hypoxic conditions often did not differ from normoxic conditions when fish were fed to satiation (Thetmeyer et al. 1999; Pichavant et al. 2001; Glencross 2009). However, a significant increase in feed conversion efficiency was reported for Nile tilapia exposed to severe hypoxia (Tran-Duy et al. 2012).

Our objective was to evaluate the performance traits and body composition of juvenile HSB reared in tanks at one of three constant dissolved oxygen concentrations $(25 \%, 40 \%$ or $100 \%$ of saturation).

\section{Materials and methods}

This research was conducted at the Harry K. Dupree Stuttgart National Aquaculture Research Center (HKD-SNARC), Agricultural Research Service (ARS), US Department of Agriculture, Stuttgart, Arkansas. Animal care and experimental protocols were approved by the HKD-SNARC Institutional Animal Care and Use Committee and conformed to ARS Policies and Procedures 130.4 and 635.1.

\section{Experimental units}

This indoor tank study consisted of three independent flow-through tank systems each comprised of a 700-L reservoir tank and four 250-L (208-L working volume) treatment tanks (experimental units). Water in each reservoir tank was managed to maintain a constant DO concentration in each of the four replicate treatment tanks of 25\% (DO25), 40\% (D040) or 100\% (DO100) of saturation by addition of pure nitrogen, air or pure oxygen. A submersible pump in each reservoir (Pondmaster Model 18B; Pentair Aquatic Ecosystems, Apopka, FL, USA) pumped water to each experimental unit at 10.7 $\mathrm{L} \mathrm{min}^{-1}$ (hydraulic retention time $=19.5$ min). A DO probe (model Type III; Oxyguard International, Birkerød, Denmark; or model D06200/T; Sensorex, Garden Grove, CA, USA) was deployed at $25 \mathrm{~cm}$ depth in each treatment tank and reservoir and DO concentration was monitored continuously by datalogger (model CR206; Campbell Scientific, Logan, UT, USA). A water temperature sensor (model 109; Campbell Scientific) was deployed at 25-cm depth in each reservoir tank and one experimental unit per DO concentration to monitor water temperature continuously by data logger. Dissolved oxygen concentration (\% saturation) averaged $23.0 \pm 2.3 \%, \quad 39.7 \pm 3.0 \%$ and $105.5 \pm 9.5 \%$ (mean \pm SD) for the DO25, DO40 and DO100 treatment tanks respectively. Each morning, the DO concentration in the DO40 and DO100 tanks was increased 2-4\% saturation to compensate for postprandial oxygen consumption, both of which are evident in the mean treatment diurnal DO curves (Fig. 1). The experiment was conducted at ambient water temperature $\left(22.6 \pm 0.6^{\circ} \mathrm{C}\right)$.

\section{Fish husbandry}

Thirty juvenile HSB $(98.7 \pm 12.3$ g; Keo Fish Farm, Keo, AR, USA; 2011 year class) were 

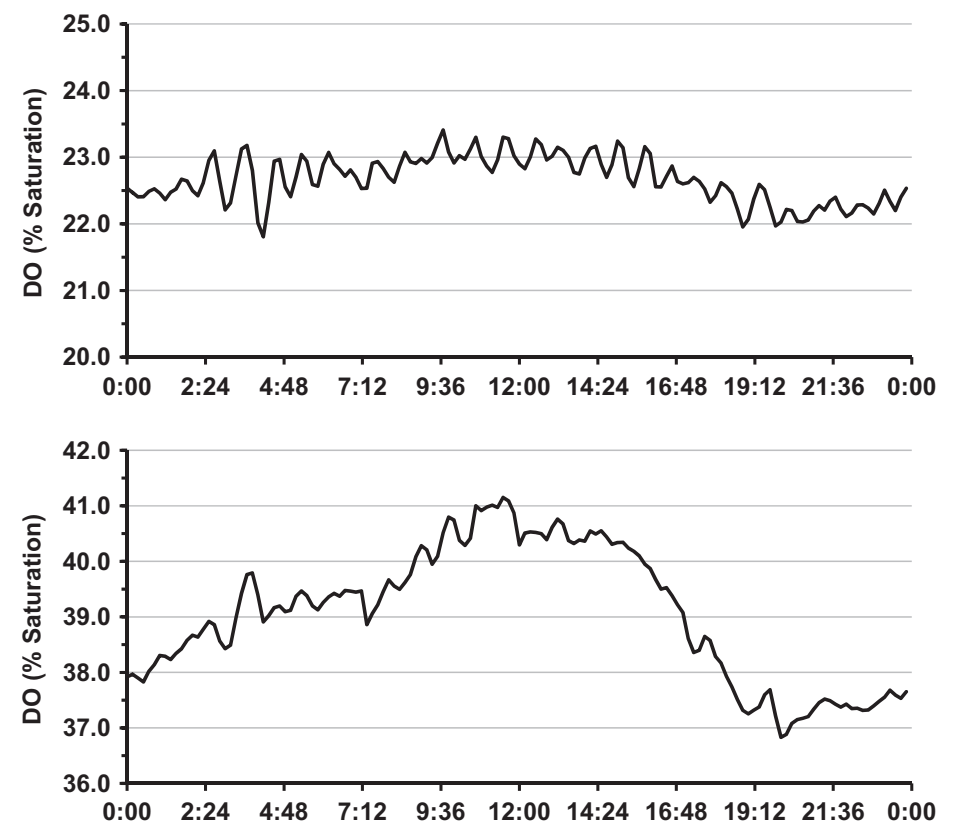

Figure 1 Mean diurnal dissolved oxygen (DO) concentration, as per cent saturation, in the DO25 (top), D040 (middle) and DO100 (bot-

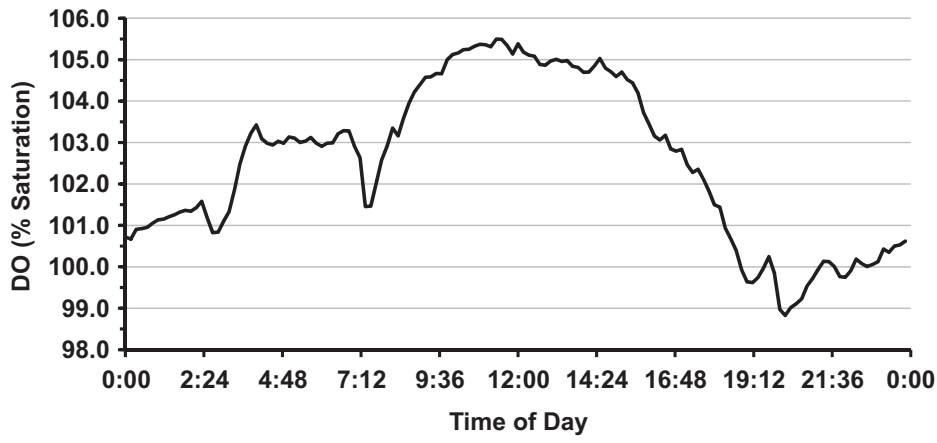
tom) treatment tanks stocked with juvenile hybrid striped bass (Morone chrysops $\times M$. saxatilis). Fish were fed daily to apparent satiation beginning about 14:00 hours. Fish were grown for 73 days at dissolved oxygen concentrations that averaged $23.0 \pm 2.3 \%, \quad 39.7 \pm$ $3.0 \%$ and $105.5 \pm 9.5 \%$ of dissolved oxygen saturation. Note that for clarity vertical axis units differ among figures.

randomly selected, tagged intramuscularly with a passive integrated transponder (PIT) tag (Biomark, Boise, ID, USA) for individual identification., and stocked into each treatment tank on 28 September 2012; initial stocking density was $14.2 \pm$ $0.5 \mathrm{~kg} \mathrm{~m}^{-3}$. Fish in each tank were fed by hand daily as much commercially formulated floating extruded feed (Cargill Animal Nutrition; 45\% crude protein, $12 \%$ crude fat) as they would consume in $30 \mathrm{~min}$. The quantity of feed fed to each tank was recorded daily. Feed conversion ratio (FCR) for each tank was calculated as the total quantity of administered feed (dry matter basis) divided by net fish production (wet weight basis).

Fish in each tank were sedated lightly and weighed individually to the nearest $0.1 \mathrm{~g}$ every 24 days and returned to their respective tank; no sampling-related mortalities occurred. All tanks were harvested 73 days after stocking. Each fish was weighed individually at harvest; each tank's total fish production was the sum of individual weights. Random samples of five and three fish were collected for determination of body compositional indices and whole body composition, respectively, at harvest during individual weighing from each treatment tank.

Body composition

Body compositional indices measured were:

Hepatosomatic index (HSI) $=$ liver mass $\times 100 \times(\text { fish mass })^{-1}$

Viscerosomatic index (VSI)

$=$ visceral mass $\times 100 \times(\text { fish mass })^{-1}$

Muscle ratio $(\mathrm{MR})=$ skin-off fillet yield with ribs $\times 100 \times(\text { fish mass })^{-1}$

Visceral mass excluded the gonads, but included all abdominal fat. 
Fish for whole body analysis were frozen for later determination of proximate composition according to standard methods (AOAC 2005; AOCS 2009). Briefly, frozen whole bodies of initial fish taken at the beginning of the trials and fish from each pond or tank at the end of the trials were thawed, homogenized and analyzed in aggregate as follows. Fish were individually ground into a fine paste using a Retsch knife mill (Grindomix GM300; Retsch GmbH, Haan, Germany) and the resulting homogenates then pooled per treatment replicate (tank, pond or initial fish) and thoroughly mixed for 1-2 min in a chilled stainless steel bowl using a commercial bench top mixer (Model A200; Hobart, Troy, OH, USA). One aliquot of each homogenate was taken for moisture determination and another $100 \mathrm{~g}$ aliquot was packed into a plastic tray and lyophilized (FreeZone ${ }^{\circledR}$ Triad $^{\text {TM }}$ freezedrier, Model 7400030; Labconco, Kansas City, MO, USA) prior to protein, lipid and energy determinations. Lyophilized samples were ground in a Thomas-Wiley mill (Model 4; Thomas Scientific, Swedesboro, NJ, USA) to produce a uniform powder for analysis. Three subsamples of each freezedried, ground homogenate were analyzed and averaged to obtain one representative analyte value per treatment replicate (tank, pond, or initial fish). Moisture was determined after drying in a convection oven (Isotemp 750F; Fisher Scientific, Hanover Park, IL, USA). Protein $(N \times 6.25)$ was determined by the Dumas method using a LECO nitrogen analyzer (FP428; LECO, St. Joseph, MI, USA). Total energy was determined by isoperibol bomb calorimetry (Parr1281 Parr Instrument, Moline, IL, USA). Lipid was determined by gravimetric quantification following petroleum ether extraction (AOCS 2009; Method AM 5-04) in an ANKOM ST15 lipid extractor (ANKOM Technology, Macedon, NY, USA). Protein or energy retention efficiency (RE) were determined by comparative slaughter and calculated as $\mathrm{RE}=$ protein or energy gain $\times 100$ /protein or energy fed.

\section{Data analysis}

Fish production, tissue composition and compositional indices data were analyzed by mixed models analysis of variance (ANOVA) or mixed models ANOVA with repeated measures (compound symmetry covariance structure) using PROC MIXED in SAS version 9.3 (SAS Institute, Cary, NC, USA). Fixed effect was treatment (DO concentration) and random effect was experimental unit (tank). Differences among least squares means were evaluated in sAS using the DIFF option with the Tukey adjustment of $P$ values. Per cent data were either arcsin or $\log$ transformed prior to data analysis (Sokal \& Rohlf 1995). Data also were subjected to linear regression using PROC REG (SAS v. 9.3).

\section{Results}

Production response variables increased significantly as DO saturation increased (Table 1). Compared to the DO25 treatment mean gain, gains for the D040 and D0100 treatments were 3.3 and 4.9 times higher respectively. Final individual weight of fish $(y)$ increased linearly in response to increased DO saturation $(y=117.983+1.199 x$, $\left.R^{2}=0.812, P<0.0001\right)$ as did gross fish yield $\left(R^{2}=0.822, \quad P<0.0001\right)$ and net fish yield $\left(R^{2}=0.819, P<0.0001\right)$.

Growth of individual fish in all treatments was linear and slopes of individual growth curves differed significantly among treatments, whereas intercepts did not. Mean individual growth curve slope $(y)$ increased linearly in response to DO concentration $(x)\left(y=0.236+0.018 x, R^{2}=0.820\right.$, $P<0.0001)$. Least squares mean individual growth curve slope was $0.418,1.318$ and 1.956 for the DO25, DO40 and DO100 treatments

Table 1 Least squares means for final fish weight ( $\mathrm{g}$ $\mathrm{fish}^{-1}$ ), individual weight gain (\%), gross fish yield (GFY, $\mathrm{kg} \mathrm{m}^{-3}$ ), net fish yield (NFY, $\mathrm{kg} \mathrm{m}^{-3}$ ) and feed conversion ratio (FCR) for juvenile hybrid striped bass (Morone chrysops $\times$ M. saxatilis) reared for 73 days in 250-L fiberglass tanks at constant dissolved oxygen concentrations of $23.0 \pm 2.3 \%$ (DO25), $39.7 \pm 3.0 \%$ (DO40) or $105.5 \pm 9.5 \% \quad$ (DO100) of saturation. Mean initial weight was $98.7 \pm 12.3 \mathrm{~g}$

\begin{tabular}{|c|c|c|c|c|c|}
\hline Treatment ${ }^{*}$ & $\begin{array}{l}\text { Final } \\
\text { weight }\end{array}$ & $\begin{array}{l}\text { Weight } \\
\text { gain }\end{array}$ & GFY & NFY & FCR \\
\hline DO25 & $126.1 \mathrm{c}$ & $28.6 \mathrm{c}$ & $18.2 \mathrm{c}$ & $4.1 \mathrm{c}$ & $2.6 \mathrm{a}$ \\
\hline DO40 & $190.0 \mathrm{~b}$ & $94.0 \mathrm{~b}$ & $27.2 \mathrm{~b}$ & $13.1 \mathrm{~b}$ & $1.4 b$ \\
\hline DO100 & $239.3 a$ & 139.0a & $34.6 \mathrm{a}$ & $20.1 \mathrm{a}$ & $1.3 \mathrm{~b}$ \\
\hline $\begin{array}{l}\text { Pooled } \\
\text { SE }\end{array}$ & 4.8 & 4.7 & 0.8 & 0.7 & 0.1 \\
\hline $\operatorname{Pr}>\mathrm{F}$ & $<0.001$ & $<0.001$ & $<0.001$ & $<0.001$ & $<0.001$ \\
\hline \multicolumn{6}{|c|}{ Linear regression } \\
\hline $\operatorname{Pr}>\mathrm{F}$ & $<0.0001$ & $<0.0001$ & $<0.0001$ & $<0.001$ & 0.013 \\
\hline$R^{2}$ & 0.812 & 0.796 & 0.822 & 0.819 & 0.477 \\
\hline
\end{tabular}

$* n=4$ replicates per treatment. Means within column followed by the same letter are not significantly different $(P>0.05)$. 
respectively. The variance among slopes for individual fish growth curves within treatment increased with increasing DO concentration, but not as rapidly as mean growth rate increased, which resulted in the mean coefficient of variation for growth rate decreasing from 36.68\% (DO25) to $23.66 \%$ (DO40) to $21.66 \%$ (DO100). Mean growth rate $\left(\mathrm{g} \mathrm{d}^{-1}\right)$ increased linearly with increased total feed intake (Fig. 2).

Total feed fed $\left(y ; \mathrm{g} \mathrm{tank}^{-1}\right)$ increased linearly with increased DO concentration ( $x$; \% saturation) $\left(y=2093.3+35.7 x, \quad R^{2}=0.839, \quad P<0.0001\right)$. Fish in tanks consumed on average a total of 2358, 4211 and $5715 \mathrm{~g}$ feed in the DO25, DO40 and DO100 treatments respectively; treatment means differed significantly from one another. Feed was utilized less efficiently by DO25 fish compared to DO40 and DO100 fish; FCR for the DO25 treatment was approximately twice that of the DO40 and D0100 treatments.

Daily feed consumption (\% biomass) was independent of individual fish weight within each DO treatment. Mean daily feed consumption $(y)$ was $1.06 \%, 1.48 \%$ and $1.71 \%$ of fish biomass for the D025, D040 and D0100 treatments, respectively, and increased linearly with increased DO concentration $(x) \quad\left(y=1.019+0.007 x, \quad R^{2}=0.762\right.$, $P=0.0002)$.

Hybrid striped bass whole body lipid, energy and moisture content were affected significantly by DO concentration whereas protein content was not (Table 2). Whole body lipid (\%, fresh weight basis; $y$ ) increased to a high of $9.0 \%$ as DO concentration $(x)$ increased to $100 \%$ saturation and was described by the linear equation $y=0.043 x+4.794 \quad\left(R^{2}=0.812, \quad P<0.001\right)$. Whole body energy (cal g ${ }^{-1}$, fresh weight basis) also increased linearly $(y=3.309 x+1522.3$, $\left.R^{2}=0.574, \quad P<0.001\right)$ with increasing DO. Whole body moisture, on the other hand, decreased linearly with increasing DO concentration $\left(y=-0.037 x+71.408, \quad R^{2}=0.511, \quad P<\right.$ 0.001). Total feed fed affected HSB bioindices significantly and was an indirect effect of DO concentration. Mean whole body lipid and energy contents increased linearly as total feed fed increased $\quad\left(R^{2}=0.900, \quad P<0.0001 \quad\right.$ and $R^{2}=0.796, \quad P<0.0001$, respectively), whereas mean whole body moisture content decreased linearly $\left(R^{2}=0.790, \quad P=0.0001\right)$ with increasing feed consumption.

Significantly larger livers (HSI) were observed in HSB reared in the D0100 treatment compared to the other two treatments (Table 2). Qualitatively, the enlarged livers were noticeably pale and soft in texture, while the other treatments collectively exhibited livers that were darkened in appearance, firm and friable. There was a positive linear relationship between HSI and DO concentration $\left(y=0.0118 x+1.728, \quad R^{2}=0.415, \quad P=0.002\right)$. Viscerosomatic index (VSI) and muscle ratio of HSB reared in the DO25 treatment were significantly lower than those indices observed at the higher DO concentrations. As DO concentration increased, VSI increased linearly $(y=0.014 x+$ $\left.5.195, \quad R^{2}=0.285, \quad P<0.001\right)$ to a high of $6.58 \%$, whereas muscle ratio increased linearly $\left(y=0.0338 x+43.776, R^{2}=0.409, P<0.0001\right)$

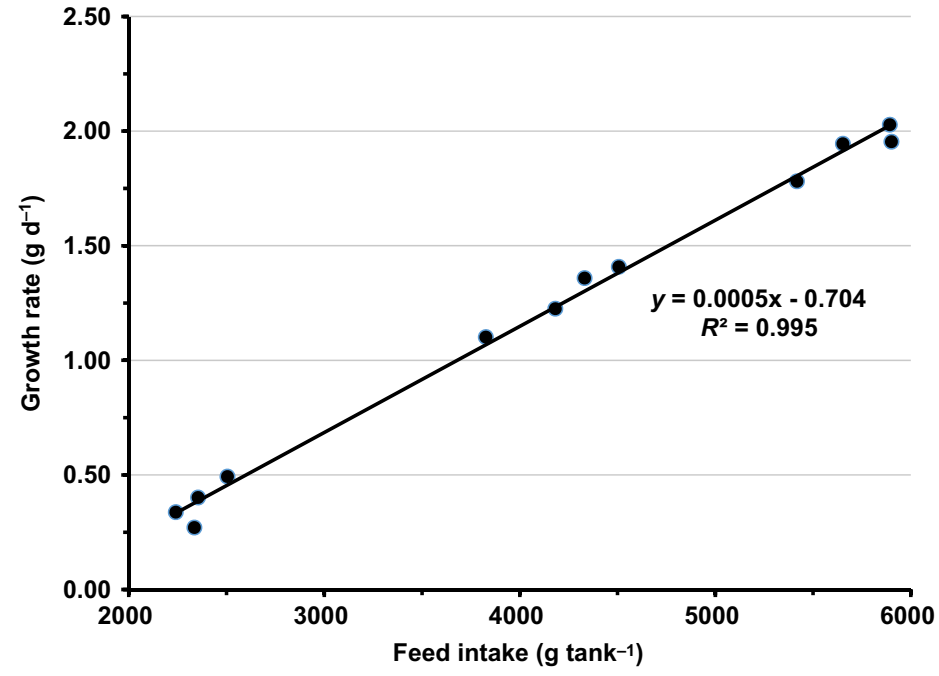

Figure 2 Mean growth rate of hybrid striped bass (Morone chrysops $\times$ M. saxatilis) in relation to total feed intake. Fish were grown for 73 days at dissolved oxygen concentrations that averaged $23.0 \pm 2.3 \%, \quad 39.7 \pm 3.0 \%$ and $105.5 \pm 9.5 \%$ of dissolved oxygen saturation. 
to a high of $47 \%$. Mean HSI $\left(R^{2}=0.586\right.$, $P=0.004)$, VSI $\left(R^{2}=0.579, P=0.004\right)$ and MR $\left(R^{2}=0.911, P<0.0001\right)$ also increased linearly as total feed fed increased.

Protein retention efficiency (PRE) increased with increasing DO concentration (Table 2) and was described by the relationship $y=0.1746 x+12.91$ $\left(R^{2}=0.648, P=0.002\right)$. Energy retention efficiency (ERE) in fish reared in the DO25 treatment (10.1\%) was less than half to a third that of fish reared in the DO40 (24.8\%) and DO 100 (32.4\%) treatments respectively. Although ERE in the two higher DO treatments did not differ according to ANOVA, a significant linear relationship $(y=0.248 x+$ 8.795; $\left.R^{2}=0.713, P<0.001\right)$ between ERE and treatment DO concentration was found.

\section{Discussion}

Aerobic metabolism is predicated on the fact that oxygen supply is critical to the utilization of energy substrates in metabolism (Kleiber 1961). Thus, it is reasonable to expect that limiting oxygen will limit dietary nutrient and energy utilization, and, hence, fish growth. Hybrid striped bass growth and body composition were affected significantly by dissolved oxygen concentration when reared in tanks at constant DO concentration. Fish growth and feed intake increased significantly as DO concentration increased. Our data show clearly that growth was linearly related to total feed intake (Fig. 2). A growth-feed intake relationship under hypoxia is reported for channel catfish (Andrews \& Masuda 1975; Buentello et al. 2000), striped bass (Brandt, Gerken, Hartman \& Demers 2009), largemouth bass (Stewart et al. 1967), turbot (Pichavant et al. 2001) and rainbow trout (Glencross 2009). At the lowest constant DO concentration (DO25) HSB not only grew more slowly because they consumed less feed but also converted consumed feed to biomass less efficiently than fish reared at higher DO concentrations. We observed that fish in the DO25 treatment fed as actively as fish in the other treatments when the daily feeding began; however, their feeding activity slowed quickly and ended sooner than for the other treatments. Similar feeding behavior was observed in response to hypoxia for brook trout (Whitworth 1968). To conserve energy, fish exposed to hypoxia reduce feeding activity (Chabot \& Claireaux 2008) and at less than 50\% DO saturation, digestion by cod (Gadus morhua Linneaus) was reduced substantially (Claireaux, Webber, Lagardere \& Kerr 2000).

An energetic explanation for reduced feed intake (Chabot \& Claireaux 2008) is supported by Pichavant et al. (2001) who found routine oxygen consumption in another moronid, European seabass, higher when fed to satiation at normoxia than at hypoxia because of the decrease in food intake in

Table 2 Least squares means ( \pm SE) for whole body analyses (on a fresh weight basis) of lipid (\%), energy (cal g ${ }^{-1}$ ) and crude protein (\%), whole-body moisture (\%), hepatosomatic index (HSI), viscerosomatic index (VSI) and muscle ratio (MR) for juvenile hybrid striped bass (Morone chrysops $\times$ M. saxatilis) reared for 73 days in 250-L fiberglass tanks at constant dissolved oxygen concentrations of $23.0 \pm 2.3 \%$ (DO25), $39.7 \pm 3.0 \%$ (DO40), or $105.5 \pm 9.5 \%$ (DO100) of saturation

\begin{tabular}{|c|c|c|c|c|c|c|c|c|c|}
\hline Treatment $^{\star}$ & Lipid & Energy & Protein & Moisture & $\mathrm{HSI} \dagger$ & vSI: & MR§ & PREף & EREף \\
\hline DO25 & $5.5 a$ & $1576 a$ & $18.4 a$ & $70.6 a$ & $2.15 b$ & $5.47 \mathrm{~b}$ & $44.0 \mathrm{~b}$ & $13.0 \mathrm{c}$ & $10.1 \mathrm{~b}$ \\
\hline DO40 & $6.9 b$ & $1691 b$ & $18.3 a$ & $69.7 a$ & $2.11 \mathrm{~b}$ & $5.85 a b$ & $45.9 a$ & $25.2 b$ & $24.8 \mathrm{a}$ \\
\hline DO100 & $9.0 \mathrm{c}$ & $1846 c$ & $18.4 \mathrm{a}$ & $67.8 \mathrm{~b}$ & $2.94 a$ & $6.58 a$ & $47.0 \mathrm{a}$ & $29.3 a$ & $32.4 a$ \\
\hline Pooled SE & 0.3 & 29 & 0.25 & 0.50 & 0.12 & 0.24 & 0.3 & 0.7 & 1.3 \\
\hline $\mathrm{Pr}>\mathrm{F}$ & $<0.001$ & $<0.001$ & 0.947 & $<0.001$ & 0.002 & 0.032 & $<0.001$ & $<0.001$ & $<0.001$ \\
\hline \multicolumn{10}{|c|}{ Linear regression } \\
\hline $\operatorname{Pr}>\mathrm{F}$ & $<0.001$ & $<0.001$ & $N^{* *}$ & $<0.001$ & $<0.001$ & $<0.001$ & $<0.001$ & 0.002 & $<0.001$ \\
\hline$R^{2}$ & 0.812 & 0.574 & & 0.511 & 0.415 & 0.285 & 0.409 & 0.648 & 0.713 \\
\hline
\end{tabular}

${ }^{*} n=4$ replicates per treatment. Means within a column followed by the same letter are not significantly different $(P>0.05)$.

$\dagger$ Hepatosomatic index $=$ liver mass $\times 100 \times(\text { fish mass })^{-1}$; values are mean determinations on 3-5 fish per tank.

$\$$ Viscersomatic index $=$ viscera mass (including abdominal fat, excluding gonads) $\times 100 \times\left(\right.$ fish mass ${ }^{-1}$; values are mean determinations on 5 fish per tank.

$\S$ Muscle ratio $=$ fillet mass $\times 100 \times(\text { fish mass })^{-1}$; values are mean determinations on 5 fish per tank.

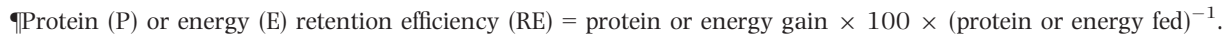

**Regression models are not significant (NS) at $P>0.05$ and $R^{2}<0.25$. 
the latter. In this study, feed intake differed markedly among oxygen levels, even between normoxia (DO100) and moderate (DO40) hypoxia; however, Burt et al. (2014) found no evidence that moderate hypoxia $(45-65 \%$ saturation) significantly impacted mRNA expression of two key regulators of fish appetite: hypothalamic cocaine- and amphetamine-regulated transcript (CART) or neuropeptide Y (NPY). Indeed, a change in leptin another appetite regulator - expression through hypoxia-inducible factor 1 (HIF-1) was evident only at severe (13\% saturation) hypoxia in zebrafish (Danio rerio Hamilton) (Chu, Li \& Yu 2010). On the other hand, HIF-1 expression was significantly increased in liver tissue of European seabass in response to both acute $\left(1.9 \mathrm{mg} \mathrm{L}^{-1}\right.$, dissolved oxygen for $4 \mathrm{~h}$ ) and chronic (4.3 $\mathrm{mg} \mathrm{L}^{-1}, 51 \% \mathrm{DO}$ saturation for 15 days) hypoxia (Terova, Rimoldi, Cora, Bernardini, Gornati \& Saroglia 2008).

At DO concentrations of 100 and $40 \%$ saturation, FCRs were remarkably similar among hybrid striped bass in our study, in spite of a $26 \%$ difference in feed consumption. Pichavant et al. (2001) also found no difference in European seabass feed efficiencies at moderate hypoxia in spite of a decline in feed intake. On the other hand, Burt et al. (2014) found distinct differences in not only feed consumption (24\%) but also feed efficiency when Atlantic salmon (Salmo salar Linneaus) were exposed to normoxia (95\% saturation) as opposed to moderate hypoxia. Although total daily feed consumption by HSB in our tanks increased significantly with increasing DO concentration, daily feed consumption as a percentage of body weight was not affected significantly by DO concentration. In contrast, daily feed consumption as a percentage of body weight was inversely related to DO for channel $\times$ blue hybrid catfish (Green et al. 2012) and Nile tilapia (Tran-Duy et al. 2012). The absence of a relationship between daily feed consumption and HSB body weight at any DO concentration in the present study likely resulted from the small range in individual weights $(0.1-0.2 \mathrm{~kg}$ fish $^{-1}$ ) observed. In contrast, individual weights ranged from 0.1 to $0.8 \mathrm{~kg}$ fish ${ }^{-1}$ in catfish studies (Green \& Rawles 2011; Green et al. 2012) and from 0.2 to $0.37 \mathrm{~kg} \mathrm{fish}^{-1}$ in Atlantic salmon studies (Burt et al. 2014), where daily feed consumption varied significantly in response to individual weight.

While fish exposed to hypoxia reduce feed intake as an energy conservation strategy, feed utilization, as expressed by feed conversion ratio or feed efficiency, reported for many tank studies (e.g. Thetmeyer et al. 1999; Pichavant et al. 2001; Glencross 2009) and for pond studies (Torrans 2005, 2008; Green \& Rawles 2011; Green et al. 2012) was unaffected by hypoxia. However, TranDuy et al. (2012) reported an FCR for Nile tilapia grown at $20 \%$ DO saturation that was 5.4-times greater than those for fish reared at $33-78 \%$ DO saturation. These authors attribute this poor feed utilization to the hypoxia-induced reduced feed intake being close to the fish's maintenance requirement. In fact, the 1-g weight gain by these fish, compared to the 36-79 g weight gain by fish in the higher DO treatments, supports their hypothesis that feed intake was close to the maintenance requirement. The significantly higher FCR observed in the DO25 treatment indicates that hypoxia affected feed utilization, but feed intake exceeded the maintenance requirement given the $29 \%$ weight gain by fish.

The results we obtained in our study both support and extend somewhat those obtained by Glencross (2009), who applied a bioenergetics approach to examine nutrient utilization with respect to hypoxia, as opposed to the apparent satiation feeding approach used here. In the former study, five ration levels, from satiation to starvation, were fed at each oxygen tension to extricate level of feed intake from oxygen effects. In our approach, in which fish were fed to satiety at each DO concentration, it is somewhat difficult to untangle variable nutrient utilization, as measured by FCR or protein and energy retention, from the variable intake we noted at each $\mathrm{O}_{2}$ level. Using the ration-level approach, however, Glencross (2009) found that between normoxic (97\%) and moderate hypoxic (42\%) DO saturations, fish reduced feed intake but protein and energy utilization efficiencies were, for the most part, unaffected. Moreover, protein retention was nonlinear with respect to intake and energy retention was linear. However, at the lowest rates of intake corresponding to the lowest maintained oxygen tensions in that study, Glencross (2009) also found indications that energy utilization, i.e. retention efficiency, marginally differed between normoxia and hypoxia within the moderate range of oxygen levels tested. It was suggested, additionally, that since respiratory quotient presumes a definitive ratio between oxygen consumption and protein [or lipid] metabolism, differences in protein and energy 
utilization may differ more than marginally, when oxygen supply is more severely restricted than the $42 \%$ saturation level tested by Glencross (2009). From this standpoint, our results present some interesting findings. In the current study, for example, FCRs and ERE were not different between $100 \%$ and $40 \%$ DO saturation and though protein retentions did differ significantly between 100\% and $40 \%$ DO saturation, they were similar in magnitude (25\% vs. 29\%). However, FCR at 25\% DO saturation was approximately twice that observed at $100 \%$ and $40 \%$ DO saturation. Similarly, protein (PRE) and energy (ERE) retentions at severe hypoxia (DO25) were lower than those observed at normoxia (DO100) to moderate hypoxia (D040). Hence, our results corroborate the relationships offered by Glencross (2009) for the same range of oxygen tensions but support the idea that dietary nutrient utilization differs markedly at oxygen concentrations of less than $40 \%$ saturation and near maintenance requirements.

The trends in feed efficiency and nutrient retention efficiencies we observed in our study are also supported by some of the changes observed in whole body composition. Whole body lipid and energy, for example, increased as the level of oxygen saturation increased, whereas whole body protein remained stable, which is compatible with an energetic point of view since lipid metabolism requires a greater amount of oxygen per unit metabolized than protein metabolism (Kleiber 1961). The opposite trends seen in whole body moisture and lipid reflect a commonly observed inverse relationship between these two body depots in relation to nutrient intake (Shearer 1994). Interestingly, though PRE declined by half with decreasing DO, whole body protein was unaltered and muscle ratio was minimally affected - declining only three percentage points. These observations reflect conservation of whole body protein metabolism and depots (Glencross 2009), even at the near maintenance feed intake level we observed at the lowest tested DO concentration.

The modest but statistically significant decrease observed in HSI from normoxia $(2.94 \%)$ to severe hypoxia $(2.11 \%)$ may be related to mobilization and loss of hepatic glycogen due to hypoxiainduced stimulation of glucose transport (GLUT2), which would be required to provide sufficient glucose substrate for an elevated ATP demand in anaerobic metabolism (Terova, Rimoldi, Brambilla,
Gornati, Bernardini \& Saroglia 2009). Similarly, the concomitant reductions in VSI, whose main components are gastrointestinal tract and its associated intraperitoneal fat, may be attributable to an increased loss of energy depots in moronid enterocytes (Terova et al. 2009), which showed the highest levels of hypoxia-induced GLUT2 expression (followed by liver), coupled with less glucose partitioned toward intraperitoneal fat via lipogenic pathways. An application of recent findings in fish bioenergetics may also help explain these observations: Glencross and Bermudes (2012) showed that as temperature stress increases there is an increase in digestible protein (DP) to DE demand. Since an indirect effect of increasing culture temperature is decreasing culture system DO, it follows that without increasing feed protein level, fish would consume less protein per feeding event given a limited amount of energy to expend in food capture, resulting in a greater portion of intake partitioned to maintenance requirements. Hence, a nutrient denser feed offered during less than optimal DO concentrations might improve protein and energy retention, and increase reserves of energy substrates in their respective depots, i.e. HSI, VSI and muscle.

\section{Conclusions}

Our results describe how performance traits and body composition of juvenile hybrid striped bass are affected by hypoxia. Total feed intake and fish growth decrease with DO concentration. Feed utilization is reduced significantly under conditions of chronic severe hypoxia (25\% DO saturation). Nutrient utilization and retention for fish reared under chronic normoxic to moderately hypoxic conditions are consistent with results from other studies, but support the idea that dietary nutrient utilization differs markedly at oxygen concentrations of less than $40 \%$ saturation and near maintenance requirements. Hence, there is a significant need for research aimed at refining both oxygen levels and mechanisms modulating feed intake in moronids for production in warmer temperature and reduced oxygen clines.

\section{Acknowledgments}

We thank Greg O'Neal and Rebecca Jacobs for their assistance throughout these studies, and Dr Catherine Childress and Matt Barnett for their 
assistance during harvest. The authors have no conflict of interest to declare. This study was funded by the USDA-ARS under project number 6225-31630-006-00D. Mention of trade names or commercial products in this article is solely for providing specific information and does not imply recommendation or endorsement by the U.S. Department of Agriculture. USDA is an equal opportunity provider and employer.

\section{References}

Andrews J.W. \& Masuda Y. (1975) The influence of various culture conditions on the oxygen consumption of channel catfish. Transactions of the American Fisheries Society 104, 322-327.

AOAC (Association of Official Analytical Chemists) (2005) AOAC Official Methods(18th edn). Association of Official Analytical Chemists, Arlington, VA.

AOCS(American Oil Chemists Society) (2009) Official Methods and Recommended Practices of the American Oil Chemists Society(6th edn). American Oil Chemists Society, Champaign, IL.

Boyd C.E. (1985) Chemical budgets for channel catfish ponds. Transactions of the American Fisheries Society 114, 291-298.

Boyd C.E. (1990) Water Quality in Ponds for Aquaculture. Alabama Agricultural Experiment Station, Auburn University, Auburn, AL.

Boyd C.E. \& Tucker C.S. (1979) Emergency aeration of fish ponds. Transactions of the American Fisheries Society 108, 299-306.

Boyd C.E., Davis J.A. \& Johnston E. (1978) Die-offs of the blue-green alga, Anabaena variabilis, in fish ponds. Hydrobiologia 61, 129-133.

Boyd C.E., Watten B.J., Goubier V. \& Wu R. (1994) Gas supersaturation in surface waters of aquaculture ponds. Aquacultural Engineering 13, 31-39.

Brandt S.B., Gerken M., Hartman K.J. \& Demers E. (2009) Effects of hypoxia on food consumption and growth of juvenile striped bass (Morone saxatilis). Journal of Experimental Marine Biology and Ecology 381, S143-S149.

Buentello A.J., Gatlin D.M. III \& Neill W.H. (2000) Effects of water temperature and dissolved oxygen on daily feed consumption, feed utilization and growth of channel catfish (Ictalurus punctatus). Aquaculture 182, 339352.

Burggren W.W. (1982) “Air gulping” improves blood oxygen transport during aquatic hypoxia in the goldfish Carassius auratus. Physiological Zoology 55, 327334.

Burt K., Hamoutene D., Perez-Casanova J., Gamperl A.K. \& Volkoff H. (2014) The erect of intermittent hypoxia on growth, appetite and some aspects of the immune response of Atlantic salmon (Salmo salar). Aquaculture Research 45, 124-137.

Carlson A.R., Blocher A. \& Herman L.J. (1980) Growth and survival of channel catfish and yellow perch exposed to lowered constant and diurnally fluctuating dissolved oxygen concentrations. Progressive Fish-Culturist 42, 73-78.

Chabot D. \& Claireaux G. (2008) Environmental hypoxia as a metabolic constraint on fish: the case for Atlantic cod (Gadus morhua). Marine Pollution Bulletin 57, $287-$ 294.

Chu D.L.H., Li V.W.T. \& Yu R.M.K. (2010) Leptin: clue to poor appetite in oxygen-starved fish. Molecular and Cellular Endocrinology 319, 143-146.

Claireaux G., Webber D.M., Kerr S.R. \& Boutilier R.G. (1995) Physiology and behaviour of freeswimming Atlantic cod (Gadus morhua) facing fluctuating salinity and oxygenation conditions. Journal of Experimental Biology 198, 61-69.

Claireaux G., Webber D.M., Lagardere J.-P. \& Kerr S.R. (2000) Influence of water temperature and oxygenation on the aerobic metabolic scope of Atlantic cod (Gadus morhua). Journal of Sea Research 44, 257-265.

Glencross B.D. (2009) Reduced water oxygen levels affect maximal feed intake, but not protein or energy utilization efficiency of rainbow trout (Oncorhynchus mykiss). Aquaculture Nutrition 15, 1-8.

Glencross B.D. \& Bermudes M. (2012) Adapting bioenergetics factorial modeling to understand the implications of heat stress on barramundi (Lates calcarifer) growth, feed utilization, and optimal protein and energy requirements - potential strategies for dealing with climate change. Aquaculture Nutrition 18, 411422.

Green B. \& Rawles S.D. (2011) Comparative growth and yield of channel catfish and channel $\times$ blue hybrid catfish fed a full or restricted ration. Aquaculture Research 41, e109-e119.

Green B.W., Rawles S.D. \& Beck B.H. (2012) Response of channel $\times$ blue hybrid catfish to chronic diurnal hypoxia. Aquaculture 350-353, 183-191.

Kleiber M. (1961) The Fire of Life: An Introduction to Animal Energetics. Wiley, New York.

Krom M.D. \& Neori A. (1989) A total nutrient budget for an experiment intensive fishpond with circularly moving seawater. Aquaculture 83, 345-358.

Pichavant K., Person-Le-Ruyet J., Le Bayon N., Severe A., Le Roux A. \& Boeuf G. (2001) Comparative effects of long-term hypoxia on growth, feeding and oxygen consumption in juvenile turbot and European sea bass. Journal of Fish Biology 59, 875-883.

Pihl L., Baden S.P. \& Diaz R.J. (1991) Effects of periodic hypoxia on distribution of demersal fish and crustaceans. Marine Biology 108, 349-360.

Porter C.B., Krom M.D., Robbins M.G., Brickell L. \& Davidson A. (1987) Ammonia excretion and total N 
budget for Gilthead seabream (Sparus aurata) and its effect on water quality conditions. Aquaculture 66, 287-297.

Schurmann H., Claireaux G. \& Chartois H. (1998) Changes in vertical distribution of sea bass (Dicentrarchus labrax L.) during a hypoxic episode. Hydrobiologia 371/372, 207-213.

Shearer K.D. (1994) Factors affecting the proximate composition of cultured fishes with emphasis on salmonids. Aquaculture 119, 63-88.

Siddiqui A.Q. \& Al-Harbi A.H. (1999) Nutrient budgets in tanks with different densities of hybrid tilapia. Aquaculture 170, 245-252.

Sokal R.R. \& Rohlf F.J. (1995) Biometry: The Principles and Practice of Statistics in Biological Research(3rd edn). W. H. Freeman and Company, New York.

Spoor W.A. (1990) Distribution of fingerling brook trout, Salvelinus frontinalis (Mitchill), in dissolved oxygen concentration gradients. Journal of Fish Biology 36, 363-373.

Stewart N.E., Shumway D.L. \& Doudoroff P. (1967) Influence of oxygen concentration on the growth of juvenile largemouth bass. Journal of the Fisheries Research Board of Canada 24, 475-494.

Terova G., Rimoldi S., Cora S., Bernardini G., Gornati R. \& Saroglia M. (2008) Acute and chronic hypoxia affects HIF- $1 \alpha$ mRNA levels in sea bass (Dicentrarchus labrax). Aquaculture 279, 150-159.

Terova G., Rimoldi S., Brambilla F., Gornati R., Bernardini G. \& Saroglia M. (2009) In vivo regulation of GLUT2
mRNA in sea bass (Dicentrarchus labrax) in response to acute and chronic hypoxia. Comparative Biochemistry and Physiology B 152, 306-316.

Thetmeyer H., Waller U., Black K.D., Inselmann S. \& Rosenthal H. (1999) Growth of European sea bass (Dicentrarchus labrax L.) under hypoxic and oscillating oxygen conditions. Aquaculture 174, 335-367.

Torrans E.L. (2005) Effect of oxygen management on culture performance of channel catfish in earthen ponds. North American Journal of Aquaculture 67, 275288.

Torrans E.L. (2008) Production responses of channel catfish to minimum daily dissolved oxygen concentrations in earthen ponds. North American Journal of Aquaculture 70, 371-381.

Tran-Duy A., van Dam A.A. \& Schrama J.W. (2012) Feed intake, growth and metabolism of Nile tilapia (Oreochromis niloticus) in relation to dissolved oxygen concentration. Aquaculture Research 43, 730-744.

Wannamaker C.M. \& Rice J.A. (2000) Effects of hypoxia on movements and behavior of selected estuarine organisms from the southeastern United States. Journal of Experimental Marine Biology and Ecology 249, 145-163.

Whitmore C.M., Warren C.E. \& Doudoroff P. (1960) Avoidance reactions of salmonid and centrarchid fishes to low oxygen concentrations. Transactions of the American Fisheries Society 89, 17-26.

Whitworth W.R. (1968) Effects of diurnal fluctuations of dissolved oxygen on the growth of brook trout. Journal of the Fisheries Research Board of Canada 25, 579-584. 